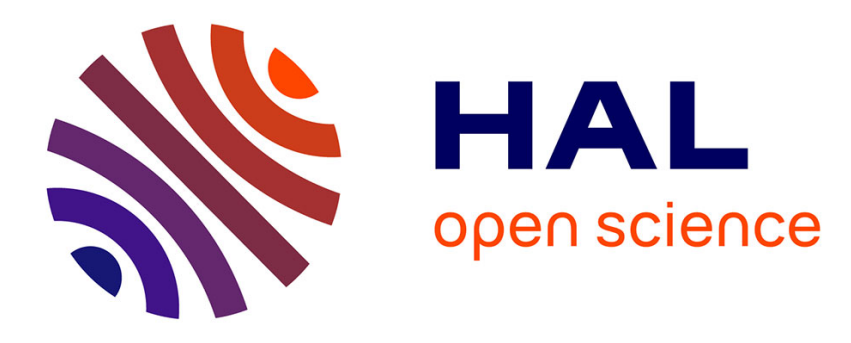

\title{
Quality of Fe3O4 Films Prepared by Plasma Assisted MOCVD
}

\author{
T. Kiyomura, M. Gomi
}

\section{To cite this version:}

T. Kiyomura, M. Gomi. Quality of Fe3O4 Films Prepared by Plasma Assisted MOCVD. Journal de Physique IV Proceedings, 1997, 07 (C1), pp.C1-611-C1-612. 10.1051/jp4:19971253 . jpa-00254961

\section{HAL Id: jpa-00254961 https://hal.science/jpa-00254961}

Submitted on 1 Jan 1997

HAL is a multi-disciplinary open access archive for the deposit and dissemination of scientific research documents, whether they are published or not. The documents may come from teaching and research institutions in France or abroad, or from public or private research centers.
L'archive ouverte pluridisciplinaire HAL, est destinée au dépôt et à la diffusion de documents scientifiques de niveau recherche, publiés ou non, émanant des établissements d'enseignement et de recherche français ou étrangers, des laboratoires publics ou privés. 


\title{
Quality of $\mathrm{Fe}_{3} \mathrm{O}_{4}$ Films Prepared by Plasma Assisted MOCVD
}

\author{
T. Kiyomura and M. Gomi \\ Department of Materials Science, Japan Advanced Institute of Science and Technology, 1-1 Asahidai, \\ Tatsunokuchi, Ishikawa 923-12, Japan
}

\begin{abstract}
Fe}_{3} \mathrm{O}_{4}$ films have been grown on $\mathrm{Si}$ substrates by plasma-assisted MOCVD using acetylacetonate iron complex as a gas source. Relationship between the deposition rate of the film and substrate temperature indicated a possibility that part of the source molecules may be decomposed into iron-oxide molecule and an intermediate by plasma applied in a diffusion process to the substrate surface. These reaction species allowed growth of $\mathrm{Fe}_{3} \mathrm{O}_{4}$ films with low carbon contamination and good surface morphology at low temperature of $400^{\circ} \mathrm{C}$.
\end{abstract}

\section{INTRODUCTION}

Metalorganic chemical vapor deposition (MOCVD) which is well known as an excellent epitaxial growth technology of semiconducting films is of interest as a promising method making ferrite films with high quality at low temperature. Torii et al. reported that thin films of $\mathrm{Fe}_{3} \mathrm{O}_{4}-\gamma-\mathrm{Fe}_{2} \mathrm{O}_{3}$ can be grown at $200^{\circ} \mathrm{C}$ or more by plasma assisted MOCVD using acetylacetonate complexes as a source [1]. Donahue et al. also reported deposition of Ba hexaferrite films by MOCVD using acetylacetonate Ba complex with ferrocene [2]. However, there have been few studies on quality of ferrite films prepared by the MOCVD so far. The film quality depends on a kind of source, diffusion process to the substrate surface and pyrolytic properties of the source molecule at the surface etc. Therefore, to investigate in details the behavior of the source molecule in the deposition process is required for obtaining good ferrite films.

In this paper, we describe growth conditions of $\mathrm{Fe}_{3} \mathrm{O}_{4}$ films and discuss relationship between the film quality and the change of the source molecule by plasma assisted.

\section{EXPERIMENTAL}

The $\mathrm{Fe}_{3} \mathrm{O}_{4}$ films were grown on $\mathrm{Si}(111)$ substrates in a low pressure MOCVD reactor. Acetylacetonate iron complex $\mathrm{Fe}\left(\mathrm{C}_{5} \mathrm{H}_{7} \mathrm{O}_{2}\right)_{3}$ was used as a gas source, which was vaporized in a reservoir kept at $140^{\circ} \mathrm{C}$. The substrate was heated to $500^{\circ} \mathrm{C}$ at maximum. A flow rate of Ar carrier gas was fixed at $18 \mathrm{ccm}$ for a constant supply of the gas source. A flow rate of oxygen for oxidizing the source molecules was also kept at $1.5 \mathrm{ccm}$. Inductively coupled plasma up to $350 \mathrm{~W}$ in incident power was applied in a position $6 \mathrm{~cm}$ away from the substrate.

Carbon contamination in the films was analyzed by X-ray photoelectron spectroscopy (XPS). The surface morphology of the films was observed by scanning electron microscope (SEM).

\section{RESULTS AND DISCUSSION}

Figure 1 shows relationship between the deposition rate of the film and the substrate temperature $T_{s}$, plotted as a parameter of incident plasma power $P_{r f}$ under a constant supply of the source. The iron oxide films were deposited at $T_{s} \geq 350^{\circ} \mathrm{C}$ without plasma assisted. As $P_{r f}$ increased, the film growth occurred at lower $T_{s}, e . g$. even at $T_{s}=120^{\circ} \mathrm{C}$ for $P_{r f}=200$ W. The $T_{s}$ dependence of the deposition rate was characterized by the following three regions; a region I seen between $120^{\circ} \mathrm{C}$ and $250^{\circ} \mathrm{C}$, in which the rate keeps a constant depending on the $P_{r f}$, a region II which shows a plateau between $300^{\circ} \mathrm{C}$ and $400^{\circ} \mathrm{C}$, and a region III exhibiting a rapid increase of the rate above $400^{\circ} \mathrm{C}$. These are presumably explained by assuming that part of the source molecules are decomposed into the following components by plasma assisted in a diffusion process to the substrate surface: One is a component completely decomposed into iron oxide by the plasma, the deposition rate of which is independent of $\mathrm{T}_{s}$. The region $\mathrm{I}$ is dominated by this component. The second is an intermediate in which $\mathrm{C}=\mathrm{C}$ bonds of organic components 


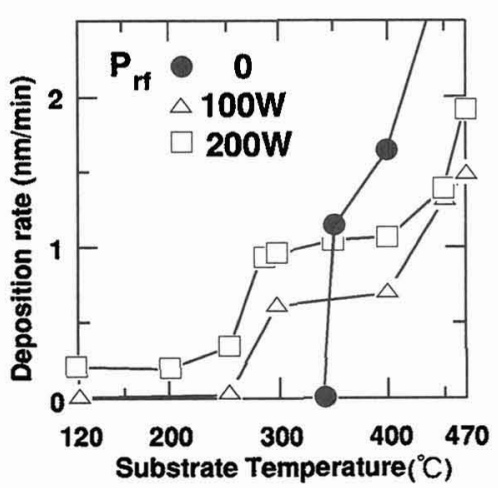

Fig. 1 Relationship between deposition rate of the film and $\mathrm{T}_{s}$, plotted as a parameter of $\mathrm{P}_{\boldsymbol{r f}}$.

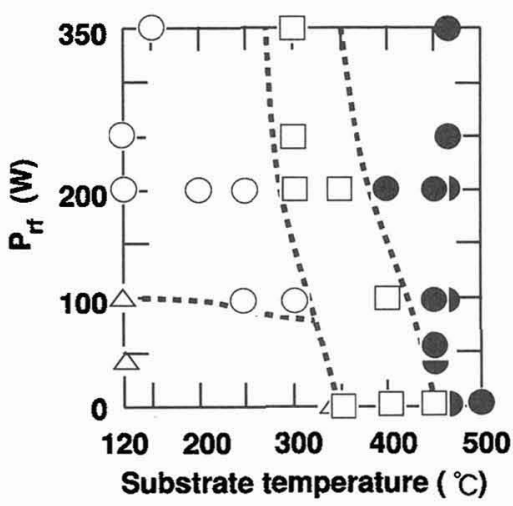

Fig. 2 Phase diagram of the films prepared at various $\mathrm{T}_{s}$ and $\mathrm{P}_{r f}: \mathrm{Fe}_{3} \mathrm{O}_{4}$ single $\mathrm{ph}$ ase, $\square \alpha-\mathrm{Fe}_{2} \mathrm{O}_{3}+\mathrm{Fe}_{3} \mathrm{O}_{4}$ mixed phase, $\mathrm{O}$ amorphous, $\Delta$ non-deposited.

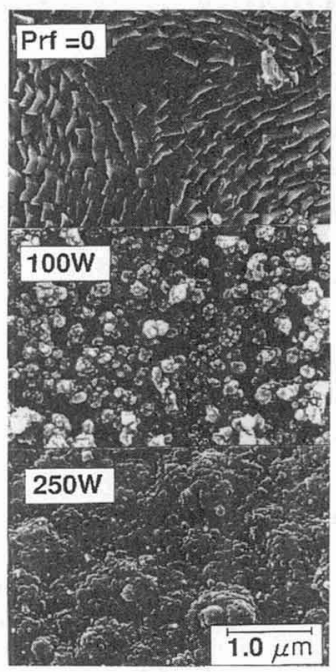

Fig. $3 \mathrm{SEM}$ micrographs of $\mathrm{Fe}_{3} \mathrm{O}_{4}$ films at $\mathrm{T}_{s}=470{ }^{\circ} \mathrm{C}$

$\mathrm{C}_{5} \mathrm{H}_{7} \mathrm{O}_{2}$ constituting the source molecule were most likely dissociated by oxygen plasma. This should be of a quasi stable state, easily decomposed at $\mathrm{T}_{\mathrm{s}}$ as low as $250^{\circ} \mathrm{C}$. The plateau observed in the region II indicates that the deposition rate was dominantly determined by the amount of this reaction species supplied to the surface. The increase of the deposition rate in the region III is due to direct pyrolysis of the source molecules itself occuring on the substrate surface, in addition to the contribution from the above two components.

Figure 2 shows phase diagram for the films prepared at various $T_{s}$ and $P_{r f}$. The films without plasma assisted were crystallized into a single phase $\mathrm{Fe}_{3} \mathrm{O}_{4}$ above a threshold temperature of $470^{\circ} \mathrm{C}$. The threshold temperature was reduced as $\mathrm{P}_{\mathrm{rf}}$ increased, as low as $400^{\circ} \mathrm{C}$ for $P_{f f}=200 \mathrm{~W}$. At lower $T_{s}$, the films were polycrystalline containing two phases of $\alpha-\mathrm{Fe}_{2} \mathrm{O}_{3}$ and $\mathrm{Fe}_{3} \mathrm{O}_{4}$, or amorphous. The range of the $\mathrm{T}_{3}$ where the mixed phase was formed, shifted to lower side as $\mathrm{P}_{\mathrm{rf}}$ increased. This would be closely associated with the intermediate produced in the diffusion process because the $T_{s}$ range corresponds to the region II described above: $\mathrm{A}$ lot of reaction species such as the quasi stable intermediate is expected to facilitate the crystallization of iron oxides at the surface. The production of $\alpha-\mathrm{Fe}_{2} \mathrm{O}_{3}$ is caused by relatively excess oxygen supplied to the reaction process in the region II where direct pyrolysis of the source molecules does not occur. The measurement of carbon contamination by XPS indicated that the atomic ratio of carbon to iron in the $\mathrm{Fe}_{3} \mathrm{O}_{4}$ film prepared at $\mathrm{P}_{\mathrm{rf}}=200 \mathrm{~W}$ decreases from $6 \%$ at $\mathrm{T}_{\mathrm{s}}=470^{\circ} \mathrm{C}$ ( the region III) to $2 \%$ at $\mathrm{T}_{s}=400^{\circ} \mathrm{C}$ ( the region II ). Thus, if the oxygen flow rate is adjusted to an optimum value, the films of $\mathrm{Fe}_{3} \mathrm{O}_{4}$ single phase as well as low carbon contamination may be expected to grow in the region II.

Figure 3 shows SEM micrographs of the surface of $\mathrm{Fe}_{3} \mathrm{O}_{4}$ films obtained at $\mathrm{T}_{s}=470^{\circ} \mathrm{C}$. The surface of the film, deposited without plasma assisted, is extremely rough, presenting a peculiar morphology, while, as plasma assisted, the films have the surfaces in which fine particles below $100 \mathrm{~nm}$ in size are aggregated densely. This result supports the above assumption that the reaction species at the surface is dominantly the completely decomposed component, that is, iron oxide molecules and the intermediate as plasma assisted. These reaction species supply a lot of nucleus and facilitate grain growth at the surface.

\section{CONCLUSION}

We have prepared $\mathrm{Fe}_{3} \mathrm{O}_{4}$ films by plasma-assisted MOCVD using the acetylacetonate iron complex. Part of the source molecules were decomposed into the iron oxide molecules and the intermediate by plasma applied in a diffusion process to the substrate surface. These made it possible to grow $\mathrm{Fe}_{3} \mathrm{O}_{4}$ films with low carbon contamination and good surface morphology at low temperature of $400^{\circ} \mathrm{C}$. Further experiments of the plasma-assisted MOCVD under optimum oxygen pressure will be required for obtaining $\mathrm{Fe}_{3} \mathrm{O}_{4}$ films with higher quality at lower temperature.

\section{References}

[1] H. Torii, E. Fujii and M. Hattori, "Preparation of Ferrite Films by Plasma Assisted MOCVD", The Sixth Int. Conf. on Ferrites, Tokyo 29 Sept.- 2 Oct 1992, T. Yamaguchi and M. Abe Eds. ( The Jpn. Soc. of Powder and Powder Metallurgy, Tokyo, 1992) pp. 464-467.

'7 E.J. Donahue and D.M. Schleich, J. Appl. Phys. 71 (1992) 6013-6017. 